\title{
Securiatity
}

$351.741: 338.24 .025 .88-071.1(497.7)$

Scientific article

\section{PRIVATIZATION OF SECURITY IN MACEDONIA: GENEALOGY AND CONTEXTUALIZATION}

\author{
Biljana Vankovska, PhD \\ Institute for Security, Defence and Peace Studies \\ E-mail: biljanav@fzf.ukim.edu.mk
}

\begin{abstract}
The paper examines genealogy of privatization of security in the Republic of Macedonia since the state gained independence from Yugoslavia in 1991. The basic premise is that the process has been complex including both external and internal factors but also it was affected by the developments that shaped the Macedonian statehood and influenced them in return. The article singles out three research questions: what were the causes of privatization of security? What shapes it has taken during the long process of democratic transition? What have been the consequences of the 2001 intra-state conflict on the privatization of security and vice versa? The starting hypothesis is that failure to achieve a satisfactory level of democratic governance during the last 25 years predetermined the state of affairs in the sphere of private security, and vice versa - the blended boundaries between State, party/parties and business interests resulted into privatization of both State institutions and security structures (be they public or private). The Macedonian case represents an adequate example of a failed democratization with perverted privatization of power and security.
\end{abstract}

Key words: privatization, security, Macedonia, state building, democratization.

\section{Introduction}

Conventional wisdom has it that privatization of security is an ongoing and widespread process on national and international level. Nevertheless, when it comes to its forms, actors and repercussions - the comparative studies display lot of differences due to the 
changeable influence of a number of factors (such as historical context, economic, political and societal milieu, etc.). It may affect military, intelligence, penitentiary and internal security realms. As privatization in general affects all spheres of modern societies and beyond, the same is true for the security sphere that not so long ago used to be an exclusive field for state monopoly over use of force.

This article is focused on a particular post-socialist state and its experiences in terms of privatization of security. Hence, the key methodological approach is a case study. Yet the introduction calls for elaboration of the way privatization of security is understood and applied in this very research. Privatization of security is both a phenomenon and process; its dialectical nature inevitably implies static and dynamic dimension as well as interplay of its causes and results. Its essence lies in the gradual move of responsibility for providing security for citizenry from governmental to nongovernmental hands (Mandel 2001, 129). This change takes place in various circumstances, so use of private security groups is commonly found both in cases of state failure or in well-developed states under the pretext of increasing efficiency and reduction of state costs related to security provision. The actors which perform these duties are also highly diverse, ranging from non-state armed actors to formally established private military/security companies. The customers also vary from governments that prefer outsourcing to multilateral peacekeeping organizations, humanitarian agencies, and corporations especially in the extractive industry (International Alert 2000, 5). Seen through the prism of these entities' organizational forms, functions and clients different sets of issues are raised. It is especially a case since 1990-ies when some analysts proclaimed the beginning of the "age of privatization" (Thompson 1996, 34). Also according to Deborah Avant $(2004,153)$ "perhaps the most dramatic incursion of the private sector into public policy is in the realm of security".

The recent history of the Republic of Macedonia witnessed a few very important developments that influenced the emergence of privatization of security. First, the state failure of former Yugoslavia meant inability to sustain state monopoly over the use of force. It opened the door for a number of non-state and para-state actors to overtake state's security functions. The ten peaceful years in Macedonia (1991-2001), unlike the other parts of former Yugoslavia, enabled the start of political transition towards liberal democracy but also economic liberalization. It was exactly the time when the first private security companies emerged in the grey zone of not fully regulated security sector. The intra-state conflict in 2001 imposed new challenges: the Albanian paramilitary forces challenged not only the state security system but also the constitutional order. The defense and especially police forces went through a process of 'privatization' that eroded the state system from within. Finally, a 


\section{Seccurity}

foreign private military company (MPRI) appeared to be involved in the conflict dynamics. The post-conflict period has brought normalization of the societal and political disturbances, while the private security sector has started to get its modern form through a more rigorous regulation and functioning alike the private security industry in developed states. In the military sphere however the globalization has been taking its price: having being involved in a number of international military interventions (such as the ones in Afghanistan and Iraq), the Macedonian soldiers have gotten in touch with foreign private entities and the contractor business has opened new job opportunities for the poorly paid and dissatisfied military and police officers. In short, also a small and newly independent state in the European periphery, the Macedonian case offers a rich ground for research of privatization of security.

For methodological purposes, the article deals with the process of privatization of security in its' military and internal security dimension.

\section{Military Dimension of Privatization of Security in Macedonia}

Dissolution of SFRY meant not only state collapse (including its security system) but also birth of a grey zone of engagement of numerous paramilitary and parapolice actors that filled the security vacuum and acted with no legal (and even less moral) ground (Kaldor 2012). No, wonder the post-conflict period witnessed a myriad of problem related to demobilization and integration of former combatants. In some cases, the newly established private security sector (private security companies - PMCs) absorbed a part of these people, while others have decided to offer their services in other war zones in the world (for the case of Croatia see Vankovska 2002).

Macedonia was the only peaceful actor in the Yugoslav drama. She avoided any violent scenario and gained independence in a peaceful manner. This fact reflects inter alia on her uniqueness when it comes to the transformation of one state security sector into another, and at the same time avoiding any parallelism in terms of security provision for the citizens. For ten years, the Republic of Macedonia was dubbed an "oasis of peace". The divorce from the rest of Yugoslavia was peaceful but the security sector had to be built from the 'ground zero': the Yugoslav People's Army removed not only its units but also all military equipment from Macedonia's territory. While some minor political forces and individuals were debating the concept of demilitarized state (state with no army) the process of birth of the new army (the Army of the Republic of Macedonia - ARM) had been ongoing. The police units and the units of the Territorial Defense were first to fill in the gap so in April 1992 they took over the border 


\section{Seccurity}

protection (Gocevski 1990). More importantly, there was no spontaneous or orchestrated formation of non-state formations (such as village guards, paramilitary forces or militias) as it was the case elsewhere in the beleaguered region (Vankovska and Wiberg 2003). The military sector was build-up out of nothing, while the police continued doing its primary job. At glance, Macedonia seemed to have moved quite smoothly towards normal democratic transition. However, the societal contradictions were smoldering beneath the surface.

Having boycotted the referendum on independence as well as the adoption of the new Constitution in 1991, the ethnic Albanian population was following the state-building process reluctantly. Because there had been few military and police officers of Albanian origin, the security structures could not reflect the ethnic composition of the Macedonian society. The perception of the army and the police depended on one's ethnic origin. Albanians were distrustful toward the Macedonian-dominated structures, while the Macedonians were enthusiastic with regard to everything that concerned their first independent state. In a few occasions, police forces intervened in the Albanian-populated regions due to mounting tensions on criminal or ethnic/political ground. With regard to the military service, the young Albanians were refusing to be recruited in the ARM, but the state officials preferred to turn their blind eye rather than to prosecute the youngsters and to likely produce unrest (Vankovska 2005). Despite the fact that all Macedonian governments were coalitions with an Albanian party as a member, there was a deep gap of distrust on a political and societal level. In November 1993, a scandal was disclosed within the ranks of the MoD. The police arrested a number of high officials of Albanian origin (including a deputy minister of defense) and charged them of attempting to establish paramilitary forces. Their intentions ostensibly would have been to separate 'lliryda' by force, and to unify it with Albania and independent Kosovo. The situation did not escalate but it was a public secret that many Albanians were illegally armed, especially after the collapse of Albania in 1997. Escalation of the Kosovo conflict echoed strongly in Macedonia, so many Albanians voluntarily joined paramilitary force across the border (UCK); as a result, many of them got useful military experience to be put in function during the 2001 conflict in Macedonia.

The 2001 conflict officially took place between the state security forces and the Albanian paramilitary forces (National Liberation Army - NLA). According to some analysts, the total number of NLA fighters was not more than two or three thousand, and "among them were a few hundred so-called 'dogs of war', who had gained experience at the fronts in Croatia, Bosnia and Kosovo. Most were Kosovars, former or current members of the Kosovo Protection Corps, KPC, who had been trained and armed by foreign advisors before and during NATO's war against Milosevic's regime. They also included a group of Mujahidin's who had been in the 


\section{Securiatity}

Balkans for a long time. These extremist formations were highly mobile, equipped with sophisticated western arms. They were the most dangerous adversaries for the Macedonian security forces but they also intimidated those Albanians in the occupied parts of Macedonia who did not agree with the NLA goals or methods" (Ordanoski 2004, 19-20).

However, there was far more than one private security actor involved in the Macedonian conflict. There were clear signs of state institutions incapacity to respond properly and timely. As the crisis was going deeper, the entropy of power structures was getting obvious. In order to provide more security the state was getting weaker - i.e. the state strength security dilemma was at place. It resulted into certain forms of 'privatization of security' on the Macedonian side of spectrum: in some villages the inhabitants self-organized in night guards, while the ruling Macedonian party (VMRO-DPMNE) was seen to have armed some civilians and party members as volunteers in order to respond to the advancing Albanian forces (Lock 2003). The already weak state was getting even weaker: the Mol organized Special Forces "Lions" in a legally dubious way (along with already existing "Tigers"). The then Minister of Interior, Ljube Boskovski, drafted volunteers mostly according to party affiliation criteria. He described the Lions as "healthy men from peasant and working class families who have Macedonia first in their hearts. There is no reason why Macedonia should be disturbed because of them ... The Lions will provide back up and logistical support for the operations of the Tigers. They'll help in cases of natural disasters, searching houses for arms, and so on." (quoted by Ordanoski 2004). Probably the most remarkable example of dysfunctional and 'privatized' state structures was the case of Johan Tarculovski (later on the Hague convict for war crimes). At the time, he served as police officer acting as an Escort Inspector in the President's Security Unit in the Mol. At one occasion, in August 2001, he led a police unit, which undertook a vengeance activity against alleged Albanian fighters in the village Ljuboten, nearby his own home village. In the verdict in the case of Ljube Boskovski (who was also put on trial but acquitted) the Hague Trial Chamber noted that "a serious failure of the functioning of the police and the responsible Macedonian authorities"; in the verdict against Tarchulovski the Chamber found that he was himself acting under orders during the operation, but "the evidence does not enable the person or persons responsible for the orders to Johan Tarculovski to be identified. The circumstances confirm it was a person or person's superior to him," (ICTY Press Release 2008).

Another element in the puzzle of privatization of security during the conflict (and even prior to it) was the involvement of an American PMC, MPRI that had already been present in Croatia, Bosnia and Kosovo (Vankovska 2002, Avant 2004). During the Macedonian conflict, i.e. the Arachinovo battle in June 2001, there were allegations that 17 'advisors' of 


\section{Securiaty}

MPRI took part on the Albanian side (Deliso 2002). Although it was hardly possible to verify the scope of engagement of MPRI (the PMC denied all allegations and due to the seriousness of the situation and the direct involvement of USA in the conflict management no objective researcher could confirm them), the company left the country under murky circumstances. However, this incident left a bitter feeling that the US government had been involved by proxy in favor of the Albanian side both in Macedonia and in the region. This sentiment has had a significant impact on the inter-ethnic relations in the years to come.

The international community (i.e. USA, EU and NATO) had been deeply involved in the conflict management and as a result, the representatives of the four main political parties signed the Framework Ohrid Agreement in August 2001. One of the first measures undertaken in the conflict aftermath was demobilization and disarmament of NLA fighters, followed by general amnesty for all participants in early 2002. Yet a comprehensive DDR project has never undertaken. The NLA top brass was quickly integrated into the political elites, following transformation of NLA into a political party (DUI) prior to the 2002 parliamentary elections. Since then they have been practically one of the coalition government's key partners but the problem of reintegration of former NLA combatants has not been resolved in a satisfactory manner. Some of these people have been involved in smaller paramilitary or criminal groups that committed various unlawful activities ever since. Demobilization of the police reservists and reparations for their health and other harms is also one of the hot issues in the Macedonian politics. In early September 2001, the NATO special envoy used the rhetoric of 'para-police forces', while the official government's stand was that they were legal part of the security system. The OSCE Mission chief concluded, "the meaning of the term 'paramilitary' often is not clear." Under external pressure, following the agreement for incorporation of the "Lions" into either police or army units this formation was disbanded. Throughout the years, a number of former NLA commanders (including even suspects in war crimes trail) have gradually joining police and army ranks. The post-conflict peace-building efforts have been put on security sector reform but with little attention on all players and actors that are not part of the public sector (Sotlar 2009, 491). The conflict aftermath witnessed an increased number of private security companies (SAS Special Report 2004, 18). There are no verified data on the number of former NLA combatants or reservists/former police officers that have turned to the private security industry.

Joining NATO and EU have become focal strategic goals especially in the post-conflict period. The military and police reforms have accelerated in hope that Macedonia will join these organizations in due time. However, the plan has been prolonged continually given the Greek blockade over the so-called name-issue. In order to satisfy its partners (primarily, the US) and 


\section{Secuurity}

to speed up the process, the government has supported the military interventions in Afghanistan and Iraq. At home, there was increasing discontent among the professional soldiers and officers who were dismissed or expected dismissal over the set age. A number of them decided to leave the Army (or police) in order to join contractor firms in Afghanistan and Iraq. The problem however has been pushed under the rug and disregarded at least on a public level. However, the state loses some of its best professionals due to better offers made by (British or the US) PMCs. The state is obviously unable to deal with the market competition with foreign PMCs. At the end of the day, all the state investments and NATO (and allies') funds that are supposed to strengthen the Army practically serve the capacities of private security actors at the international level.

\section{Internal Dimension of Privatization of Security in Macedonia}

The new liberal political and economic system was introduced on a normative and formal level relatively quickly in 1991 but the process of institution building and particularly of democracy building has been quite troublesome. The process publicly known as 'criminal privatization' took place in the economic sphere: the societal ownership was transformed into private ownership in a way that has generally been seen as dubious. It was followed by redistribution of social wealth, while societal inequality as well as the increase of unemployment rate has become a constant feature of Macedonia's transition. Hence, privatization as such has negative meaning in the collective awareness of the citizens. The transition's effects have been disastrous and long lasting. Nevertheless, the state has come under the sway of (crony) capitalism alike the other post-socialist states. In that, respect Horvat and Stiks (2012) rightly point out the following regional situation: "In spite of the rhetoric of incompleteness, we can observe that the free market reigns supreme; post-socialist Eastern Europe is fully incorporated into the capitalist world in a semi-peripheral role. In practice, this means the availability of cheap and highly educated labor in proximity to the capitalist core, a quasi-total economic dependence on the core and its multinational banks and corporations, and finally the accumulation of debt. On the political side, liberal democratic procedures formally seem to be there." Liberalization,market deregulation and privatization have become three holly words of neoliberal modernization; yet the expected success is missing. One should however keep in mind that privatization has been under harsh critique even in the most developed states. For instance, some authors argue that "neoliberal privatization is suffering from a legitimacy crisis, an efficiency crisis (concerning prices, quality 


\section{Seccurity}

and access), and a crisis of profitability - but crises do not necessarily lead to an end to privatizations, rather they lead to new ways and strategies for making them more effective" (Candeias, Rilling and Weise, 2008). In this context, a question about privatization of security imposes itself: is it possible to distinguish "private security industry" from the rest of the private business? Could it be a success story under such societal and economic circumstances? What success and for whom?

The appearance of the first private security companies in former Yugoslav countries coincided with the transformation of the economic and political system at the beginning of the 1990s (Mesko et al. 2004). Actually, "re-birth" of private property (Sotlar 2009, 491) and neoliberal economics provided 'need' for new forms of providing security for private purposes. Comparison with developed states and arguing for the intrinsic necessity of 'plural policing' in a weak state with de facto no economy is somewhat problematic, especially in terms of the legitimacy and credibility of the private security services. It will take long time to come to terms with criminal privatization and with the notion that many businesspersons and rich people may have earned their capital and are allowed to use non-state security services. Weak state by default rests on a security apparatus to keep the problematic society together thus being entangled in state-strength dilemma (Holsti 1996). Its economic and other weaknesses result into weak police forces and inept and corrupted state administration that make many people prefer paying for their safety. Tholens and Strazzari $(2008,2)$ quite accurately spell out the dilemma between the democratization, state-building process and privatization of security arguing that "delicate questions of political loyalty and clienteles blend with externally imposed imperatives to decrease state expenditures and create a free-market economy, creating a market for private security services."

The methods of development of the new security business in post-socialist states correspond to the developments in Macedonia. Cvetkovski $(2014,3-4)$ rightly points out: "In such blurred, fluid circumstances and not-regulated conditions and criteria, the initial appearance and practice of private security was following two obvious paths. The first one referred to establishment of private agencies at service of the new 'businessmen', celebrities, controversial politicians as well as of certain structures of organized crime. The second path of emergence and development has been going through formation of private agencies that overtook the job of the former in-house guards and keepers employed in the socialist state enterprises. Typical for both ways of development of this new transitional business was their becoming synonyms for racketeering, blackmail etc. as a result of symbiosis between the organized crime structures and corrupted government." 


\section{Seccurity}

Number of (retired or active) police professionals, who took initiative to launch the new business as early as in 1994, saw private security as a window of opportunity. The development of the private security sector has been advancing with some characteristic features. Each power elite was assisting birth of new enriched "businessmen", who needed protection of their welfare and businesses offered by private security firms. In the words of the former minister of interior Pavle Trajanov, "in the first years after the independence it was a matter of prestige for anyone who had gained certain capital to engage a bodyguard, to be seen at public places surrounded by armed people, who were often with shaved heads. Some of those wild agencies got involved into operations of enforced debt-collection, racketeering, disturbance of public order, and even physical attacks, etc." (Komora na Republika Makedonija za privatno obezbeduvanje, 2015: 28).

Privatization and liberalization of the market for private security services in Macedonia has been carried out with practically no institutional or legal experiences in this sphere. In former Yugoslavia (and for the same matter in Macedonia) there was a legal and state-sponsored activity of protection of property and persons, which was an integral part of the Directorate for Public Security, i.e. Ministry of Interior. The assets under protection were in societal property, while the Law on Societal Self-Protection regulated the competences of the police officers in this realm. Yugoslavia's disintegration did not mean automatic suspension of the inherited legal system. To the contrary, it was a gradual and painful process. It took quite some time after the adoption of the 1991 Constitution of independent Macedonia to bring new legislation in various spheres. When it comes to private security regulation, the period between 1991-1999 was limbo, a grey zone (particularly, having in mind that the first private security agency was established in 1994): there were individuals and groups with interest and with some professional experience but they carried out their business with no clear regulation. The compromise solution was to establish a firm for a vast range of services where security services were enlisted as "other". Since 1994, the number of private security firms has been growing steadily depending on the market needs, sustainability and competition. The 1999 law established the first legal criteria in this sphere, which mean elimination of all those actors who were unable to adapt to the legal requirements.

At some point, the focal point of market competition was the licensing as business per se. Establishment of a special (commerce-like) chamber for security of persons and property was of a crucial importance. At one point, two competing chambers offered their services to the growing number of people who saw private security services as a matter of making for their living (Crvenkovska 2009). Only when this situation was clarified i.e. the law 


\section{Seccurity}

stipulated that there should be one single Chamber - things moved in a more regular direction.

This dualism opened a public debate over the status of private security industry - or more precisely, about the exact number of people under arms in addition to the regular police and army structures. The second crucial issue refers to their direct or indirect links to the police top brass, power centers and political parties. For instance, in 2006 a journalist noticed that high police officials from the city (Karevski 2006) managed all PSCs in Bitola, with exception of only one. Some analysts treat them as para-police structures that outnumber the total capacity of the state police structures.

The official web site of the Chamber for Private Security currently displays the names and other data of 43 private security companies (with not a single foreign firm among them). Certain data from different sources have been indicating far bigger number of agencies but in reality not all of them have been active all the time (which is the case with all commercial subjects regardless the realm of work). The fact that some economic subjects have their inhouse security staff makes the whole picture more complex and it is hard to give exact figures of employees in the private security field. Having in mind the economic and societal context, one could hardly expect a developed security industry in a poor and economically weak state. The reality check shows that the most of the active PSCs are with small capacities (the number of employees per security agency ranges from 5-10 people up to 200). According to the available data of the Confederation of European Security Services (COESS), three top agencies concentrate in their hands the biggest share of the security services' market - $47 \%$ in total. In 2010, there were 165 registered private security agencies, out of which only 135 were active. In total, the number of employees reached 4000 . According to the dada of the Central Register Office of the Republic of Macedonia, in April 2016, only 64 legal subjects have been involved in the private security business with 2171 employees. Seen through the time prism, since 1994 up to date, things have evidently moved from a grey zone to a well-regulated commercial sector with improved professional performances. What used to be an exception or something associated with protection of the members of the elite, today becomes an everyday phenomenon. The members of various private security agencies may be seen on a number of public spaces, events, and even as security guards of some state institutions. The number of private (individual) clients is still insignificant as a source of profit due to a number of reasons but it is obvious that the State is the main and the richest client of some PSCs, selected primarily on the ground of their closeness to the ruling party/parties. 


\section{Seccuritity}

\section{Conclusion}

The analysis shows that when it comes to the military dimension of privatization of security, the country has a rather dubious experience with a foreign PMC, and suffers the effects of export of its own military stuff to PMCs abroad. In terms of the internal dimension the Republic of Macedonia deals with similar legacies and faces same challenges as the ones present in the neighboring countries especially with regard to weak legal regulations, unprincipled market competition, and insufficient democratic control.

The state of affairs in the field of private security is a consequence of the general economic and political standing of the country. For instance, synergy and personal ties between former and current high police officials within partitocrazia provide vast opportunities not only for lucrative deals but also even for privatization of State as such. For quite some time prior to the escalation of the current political and constitutional crisis, the situation in Macedonia had been described in the following way: "Macedonia's governance may best be described as formally democratic. This qualification reflects a number of problems affecting the country, including clientelism, nepotism and corruption, a weak and politicized administration, restrictions on freedom of the media and a growing fixation on "national" issues." (Denhert 2010). The future challenges in this realm include dubiousness of the transfer of police duties to PSCs workers due to the alleged similarity of public and private security officers that calls for their equal treatment. In addition, there are still warnings about possible violation of human rights and democratic principles.

\section{Bibliography}

1. Avant Deborah, "The Privatization of Security and Change in the Control of Force", International Studies Perspectives, 5 (2004).

2. Candeias M., R. Rilling and K. Weise, "Crisis of Privatization - Return of the Public Sphere", RLS Policy Paper, no. 1, 2008

3. Crvenkovska Natasa, "Nestabilnost vo sektorot na bezbednosta", Globus, 22 September 2009, available at:

http://www.globusmagazin.com.mk/?ItemID=95865D023B9BF14593CA89F360AF35F $\underline{2}$ (accessed on 10 October 2016)

4. Cvetkovski Grozdan, Razvojot i perspektivite na privatnata detektivska dejnost kako know-how profesija vo postkomunistickite drzavi, Sofia: Balkan Analitika, 2014 


\section{Sececurity}

5. Deliso Christopher, "Macedonia - A Connection Between NATO and the NLA?", Antiwar, 23 January 2002, available at http://www.freerepublic.com/focus/news/613620/posts?page $=107$

6. Denhert Stefan, "Elections and Conflict in Macedonia", FES Country Analysis, February 2010

7. Dimitrievski Aleksandar, "Talat Dzaferi go potvrdi unapreduvanjeto na Shevalj Etemi", TV Alfa, 7 October 2013, available at:

http://www.alfa.mk/News.aspx?ID=64339\#.VzsY0zV97IU (accessed on 9 October 2016)

8. Gocevski Trajan, Kolektivnata bezbednost i odbranata na Makedonija, Kumanovo: Prosveta, 1990

9. Horvat Srecko and Igor Stiks, "Welcome to the Desert of Transition! Post-Socialism, the European Union, and a New Left in the Balkans", Monthly Review, vol. 63, issue 10, March 2012, available at: http://monthlyreview.org/2012/03/01/welcome-to-thedesert-of-transition/ (accessed on 10 October 2016)

10. ICG Report "Macedonia: No Time for Complacency", October 2003, available at: http://www.crisisgroup.org/en/regions/europe/balkans/macedonia/149-macedoniano-time-for-complacency.aspx (accessed on 9 0ctober 2016)

11. ICTY Press Release, Boškoski Acquitted and Tarčulovski Sentenced to 12 Years' Imprisonment, 10 July 2008, available at http://www.icty.org/sid/9943 (accessed on 9 October 2016)

12. International Alert, Privatization of Security and Peacebuilding: A Framework for Action, IA: London, 2000.

13. Jones T. and T. Newburn, Private Security and Public Policing, Oxford: Oxford University Press, 1993

14. Karevski Goce, "'Стрежево' ги отпушти чуварите и ангажира приватна агенција", Utrinski vesnik, 16 0ctober 2006, available at: http://star.utrinski.com.mk/?pBroj=1523 HYPERLINK "http://star.utrinski.com.mk/?pBroj=1523\&stID=18767\&pR=3"\& HYPERLINK "http://star.utrinski.com.mk/?pBroj=1523\&stID=18767\&pR=3"stID=18767 HYPERLINK "http://star.utrinski.com.mk/?pBroj=1523\&st|D=18767\&pR=3"pR=3 (accessed on 9 0ctober 2016)

15. Lock Lars, Macedonia: A Conflict Analysis, SIDA, 2003 


\section{Sececurity}

16. Kalajdziev Gordan, "Privatno obezbeduvanje ili parapolicija", Mislenje na "Transparentnost Makedonija", December 2012, available at: http://www.transparentnost-mk.org.mk/Upload/dokumenti/20121207Mislenje-zaPredlog-Zakonot-za-privatno-obezbeduvanje(1).pdf (accessed on 9 October 2016)

17. Komora na Republika Makedonija za privatno obezbeduvanje 2000-2015, Skopje: Komora na Republika Makedonija za privatno obezbeduvanje, 2015.

18. Mandel Robert, "The Privatization of Security", Armed Forces and Society, vol. 28, no. $1,2001$.

19. Mesko et al (eds.), Policing in Central and Eastern Europe, Dilemmas of Contemporary Criminal Justice, Ljubljana: Faculty of Criminal Justice, 2004.

20. Ordanoski Sasho, "Lions \& Tigers The Militarisation of the Macedonian Right", in: The 2001 Conflict in FYROM - Reflections, Conflict Studies Research Centre, June 2004, available at: http://isndemo.atlasproject.eu/asset demo/file/1b5303b9-d218-4cccb009-8f41c86a8461/d3b1d8a9-ecb6-4063-8b13-c4177bf822c0/[4].pdf (accessed on 9 October 2016)

21. Popovic Z. and Z. Gajic (eds.), Kroz tranziciju: prilozi teoriji privatizacije, Novi Sad: AKO, 2011

22. Small Arms Survey Report. Grillot, S., Paes, W., Risser, H., Stoneman, S. (eds.), A Fragile Peace: Guns and Security in post-conflict Macedonia. UNDP and the SAS, SEESAC 2004

23. Sotlar Andrej (2009),"Post-conflict private policing: experiences from several former Yugoslav countries", Policing: An International Journal of Police Strategies \& Management, vol. 32, no 3

24. Thompson Mark, "Generals for Hire," Time, 147 (January 15, 1996).

25. Vankovska Biljana, "Ethnic-Military Relations in Macedonia". In Albrecht Schnabel and Hans-Georg Ehrhart (eds.) Security Sector Reform and Post-Conflict Peacebuilding, Tokyo: UNU Press, 2005.

26. Vankovska Biljana, "Privatisation of Security in Croatia" in Damian Lilly and Michael von Tangen Page (eds.), Privatisation of Security and Security Sector Reform, (London: International Alert, 2002): 55-90 